\title{
HAMBATAN EPISTEMOLOGI SISWA DALAM MENYELESAIKAN MASALAH BANGUN RUANG SISI DATAR
}

\author{
${ }^{1}$ Nining Sifa Elfiah, ${ }^{2}$ Hevy Risqi Maharani, ${ }^{3}$ M. Aminudin \\ ${ }^{1,2,3}$ Pendidikan Matematika, Fakultas Keguruan dan Ilmu Pendidikan, Universitas Islam Sultan Agung \\ ${ }^{1}$ niningsifa@std.unissula.ac.id, ${ }^{2}$ hevyrisqi@unissula.ac.id, ${ }^{3}$ aminudin@unissula.ac.id
}

Received : $14 / 10 / 2019$

Accepted : 29/01/2020

Published : 31/01/2020

\begin{abstract}
The purpose of this study is to find out what are the epistemological barriers of students in solving the problem of getting up the flat side space. This research method used descriptive qualitative method with data collection methods including tests, think aloud, and interviews. Subjects were selected from class VIIIA at MTs NU 1 Warureja where the subject search method was carried out by the test method. Then three students who have obstacles and communicative were chosen to do further research used think aloud and interview methods. The results of this study indicate that conceptual obstacles occuredr because the three subjects had not been able to analyze the concept of the questions given and their laziness experienced. Procedural obstacles occurred because the three subjects had not been able to recognize the conditions given by a concept. Operational technical obstacles occurred because the three subjects are still not careful and thorough in answering a problem.
\end{abstract}

Keywords: epistemological obstacles, problem solving

\begin{abstract}
Abstrak
Tujuan penelitian ini yaitu untuk mengetahui apa saja hambatan epistemologi siswa dalam menyelesaikan masalah bangun ruang sisi datar. Metode penelitian ini menggunakan metode kualitatif deskriptif dengan metode pengambilan data meliputi tes, think aloud, dan wawancara. Subjek dipilih dari kelas VIIIA di MTs NU 1 Warureja dimana metode pencarian subjek dilakukan dengan metode tes. Kemudian dipilih tiga siswa yang memiliki hambatan epistemologi dan komunikatif untuk dilakukan penelitian lebih lanjut dengan metode think aloud dan wawancara. Hasil penelitian ini menunjukkan bahwa hambatan konseptual terjadi dikarenakan ketiga subjek belum dapat menganalisa konsep soal yang diberikan dan rasa malas yang dialaminya untuk menuliskan rumus yang diperlukan. Hambatan prosedural terjadi ketiga subjek belum mampu mengenali kondisi yang diberikan oleh suatu konsep. Hambatan teknik operasional terjadi dikarenakan ketiga subjek masih kurang cermat dan teliti dalam menjawab suatu permasalahan.
\end{abstract}

Kata Kunci: hambatan epistemologi, penyelesaian masalah

\section{Pendahuluan}

Penelitian yang akan peneliti lakukan adalah penelitian tentang hambatan epistemologi siswa dalam menyelesaikan masalah bangun ruang sisi datar. Sebelumnya peneliti sudah melakukan sebuah observasi dengan memberikan sebuah soal kepada satu orang siswa. 
Perhatikan gambar di bawah ini

\begin{tabular}{|l|l|}
\hline & $\begin{array}{l}\text { Jika diketahui panjang: } \\
\mathrm{AB}=5 \mathrm{~cm}, \mathrm{BC}=5 \mathrm{~cm}, \mathrm{CG}=10 \mathrm{~cm}\end{array}$ \\
& $\begin{array}{l}\text { dan tinggi bangun } 15 \mathrm{~cm}, \text { maka tentukan: } \\
\text { a. Luas permukaan bangun tersebut! }\end{array}$ \\
\hline & b. Volume bangun tersebut! \\
\hline
\end{tabular}

Siswa mengalami kesulitan dalam menyelesaikan soal tersebut. Dari jawaban, siswa hanya bisa menjawab sampai luas permukaan balok saja. Kemudian siswa berusaha untuk mencari penyelesaian dari masalah lain, tetapi hal ini tidak ia lakukan sampai selesai. Siswa mengalami kendala dalam melanjutkan jawaban sampai selesai.

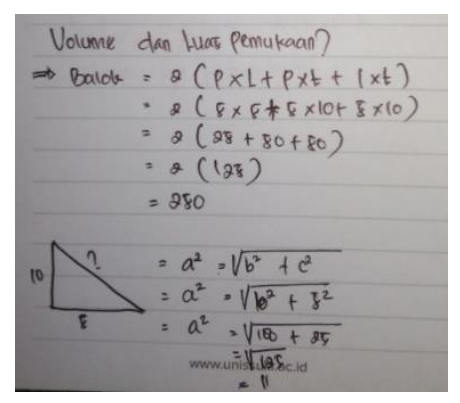

Gambar 2 Jawaban Soal Observasi Siswa

Setelah melihat jawaban siswa, terlihat siswa banyak mengalami hambatan yang sesuai dengan indikator hambatan epistemologi menurut Kastolan (1992), yaitu hambatan konseptual, hambatan prosedural, dan hambatan teknik operasional. Sehingga dari sampel di atas, membuktikan bahwa penelitian tentang hambatan epistemologi siswa dalam menyelesaikan masalah pada materi bangun ruang sisi datar itu penting untuk dilakukan.

Hayati (2009) siswa biasanya hanya mengandalkan penjelasan dari guru dalam proses pembelajaran. Contoh soal yang diberikan guru pasti dijadikan dasar untuk belajar siswa, dan siswa hanya terpaku dengan jenis soal seperti pada contoh soal tersebut. Sehingga ketika guru memberikan soal dengan bentuk berbeda dari contoh soal siswa akan kebingungan dan tidak dapat memahami konsep dari soal. Hal ini menjadikan pengembangan kualitas berpikir kreatif menjadi salah satu tujuan utama pendidikan (Maharani, Sukestiyarno, Waluya, \& Mulyono, 2018). Pemanfaatan konsep bangun ruang sisi datar menjadikan pentingnya materi ini untuk dipelajari. Namun kenyataannya pentingnya materi bangun ruang sisi datar tidak sebanding dengan kemampuan pemahaman siswa. Apalagi memahami bangun tiga dimensi baik secara real maupun gambar merupakan tantangan bagi siswa (Xiao \& Kenan, 2018). Tantangan ini 
banyak menyita waktu. Padahal siswa cenderung malas untuk mengerjakan soal yang banyak menyita waktu (Sears, 2018). Hal ini terbukti dengan banyaknya penelitian yang membahas tentang kesulitan-kesulitan yang dialami siswa pada materi bangun ruang sisi datar. Begitu juga yang terjadi di MTs NU 1 Warureja yang menjadi tempat penelitian. Pada Puspendik Kemdikbud pada tahun ajaran 2017/2018 jumlah persentase siswa yang menjawab benar pada materi geometri dan pengukuran dalam hal ini bangun ruang sisi datar hanya 28,62\%. Masih lebih sedikit dari persentase nasional dengan jumlah 41,40\%.

Berbagai masalah-masalah kesulitan siswa dalam memahami konsep merupakan contoh dari hambatan epistemologi. Penyebab kesulitan belajar siswa menurut Brousseau (Dedy, E., \& Sumiaty, E., 2016) ada 3 faktor yaitu: hambatan ontogeni (kesiapan mental belajar), hambatan didaktis (akibat pengajaran guru), dan hambatan epistemologi. Hambatan epistemologi merupakan suatu hambatan dimana pengetahuan siswa memiliki konteks aplikasi yang terbatas. Siswa yang memiliki konteks aplikasi pengetahuan terbatas akan mengalami kesulitan dalam menerima pengetahuan baru, karena siswa hanya berpatok pada pengetahuan yang sudah ada. Hambatan epistemologis merupakan hambatan yang sulit untuk dihindari oleh siswa, karena hambatan epistemologi sendiri ada di dalam konsep atau pengetahuan itu dan juga hambatan epistemologi itu dapat dianalisis dari sejarah konsep atau dari pengetahuan tersebut (Brousseau, 2002). Menurut Hanafi (2015) hambatan epistemologis berhubungan erat dengan kesalahan dan kesulitan yang terjadi pada objek kajian abstrak matematika, objekobjek matematika yang dimaksud diantaranya adalah operasi, konsep, prinsip, dan fakta.

Adapun rumusan masalah dalam penelitian ini adalah bagaimana bentuk hambatan epistemologi siswa dari kelas VIIIA di MTs NU 01 Warureja dalam menyelesaikan masalah bangun ruang sisi datar.

\section{Metode Penelitian}

Jenis penelitian ini yaitu penelitian kualitatif deskriptif menggunakan pendekatan studi kasus dengan mengambil subjek dari kelas VIIIA di MTs NU 1 Warureja Tegal. Instrumen yang digunakan dalam penelitian ini berupa soal untuk tes dan think aloud, serta pedoman wawancara. Data penelitian diambil dengan metode tes untuk mencari subjek dari kelas VIIIA, tes think aloud untuk meneliti hambatan yang dialami subjek, dan terakhir metode wawancara untuk mendapatkan informasi yang belum didapatkan pada metode sebelumnya. Kriteria subjek yang dipilih yaitu siswa yang memiliki hambatan dan komunikatif. Hambatan yang dimaksud yaitu hambatan epistemologi dari Kastolan (1992) dengan indikator hambatan konseptual, hambatan prosedural, dan hambatan teknik operasional. Berikut contoh soal yang akan digunakan untuk penelitian. 
Sebuah kue berbentuk kubus memiliki panjang sisi $18 \mathrm{~cm}$. Kue diiris hingga sisanya seperti gambar berikut.

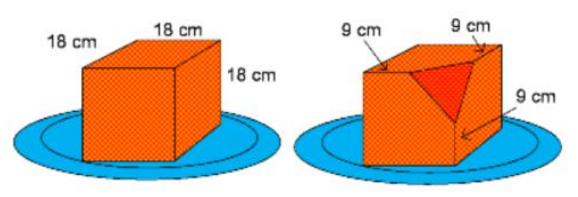

Gambar 3 contoh soal penelitian

Tentukan volume sisa kue di atas piring! (Potongan kue berbentuk limas segitiga sama sisi)

\section{Hasil dan Pembahasan}

\subsection{Hasil Penelitian}

Penelitian diawali dengan pencarian subjek dengan melakukan metode tes pada tanggal 25 Juli 2019, dimana sasaran dari penelitian ini adalah siswa kelas VIIIA di MTs NU 1 Warureja. Dari kelas VIIIA yang berjumlah 32 siswa, kemudian hasil tes dianalisis untuk disortir dan dipilih tiga siswa yang memenuhi kriteria. Kriteria subjek yang dipilih adalah siswa yang mempunyai banyak hambatan dan komunikatif. Hambatan yang dimaksud yaitu hambatan epistemologi dengan indikator hambatan konseptual, hambatan prosedural, dan hambatan teknik operasional. Sedangkan untuk mengetahui siswa komunikatif, peneliti menunjuk semua siswa untuk berbicara di depan kelas satu per satu. Sebelumnya sudah dilakukan validasi instrumen oleh dosen pembimbing dan juga guru pengampu pada instrumen tes pencarian subjek. Berikut adalah data hasil pemilihan subjek penelitian.

Dari 32 siswa kelas VIIIA didapatkan 27 siswa yang mempunyai hambatan dan 5 siswa yang tidak mempunyai hambatan. Sedangkan dalam segi komunikatif, terdapat 13 siswa yang komunikatif. Selebihnya sebanyak 19 siswa termasuk siswa yang kurang komunikatif. Menurut hasil analisis terdapat delapan siswa yang memenuhi dua kriteria untuk dijadikan subjek penelitian. Karena beberapa siswa mempunyai hambatan yang sama, maka peneliti mengambil tiga siswa untuk dijadikan subjek penelitian yang bisa mewakili hambatan dari siswa yang lain. Subjek penelitian tersebut diantaranya AK (S1), AA (S2), dan SN (S3).

Penelitian pada hari kedua yaitu pada tanggal 26 Juli 2019 dilakukan think aloud dan juga wawancara. Berikut hasil pekerjaan siswa pada saat think aloud dan wawancaranya.

Berikut penjabaran hasil penelitian tentang hambatan epistemologi yang dialami ketiga subjek yang meliputi indikator hambatan konseptual, hambatan prosedural, dan teknik operasional. 


\section{Hambatan Konseptual}

Pada hambatan konseptual, semua indikator hambatan dapat ditemukan pada instrumen jawaban dari semua subjek. Pada indikator kesalahan dalam menentukan rumus dilakukan oleh S1 dan S2 pada soal nomor 1 serta S3 pada soal nomor 2. Soal nomor 1 diharuskan mencari luas permukaan balok, tetapi S1 dan S2 mencari volume balok.
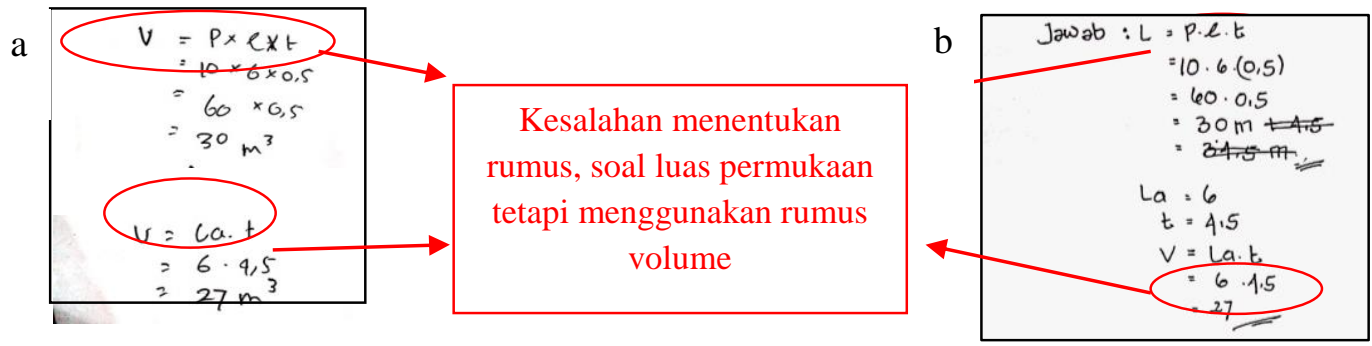

Gambar 4 Kesalahan menentukan rumus oleh S1(a) dan S2(b)

Pada saat wawancara, S1 menyadari bahwa ia melakukan kesalahan dalam menentukan rumus pada saat mengerjakan soal nomor 1. Berbeda dengan S1, S2 dengan terang-terangan mengaku bahwa ia memang tidak dapat memahami konsep soal nomor 1 . Menurut S2, soal tersebut susah dan tidak seperti biasanya. Karena memang jenis soal yang diberikan merupakan pengembangan soal standar yang hanya memberikan satu bangun ruang untuk dicari volume atau luas permukaannya. Sedangkan soal pengembangan yang dijadikan soal penelitian ini yaitu soal dimana bangun yang terbentuk dari gabungan dua bangun ruang. Seperti pada soal nomor 1, merupakan gabungan dari balok dan prisma.

Pada soal nomor dua, S3 melakukan kesalahan yaitu mencari volume potongan kue dengan menggunakan rumus kubus. Padahal sudah jelas dalam soal tertulis bahwa potongan kue berbentuk limas bukan kubus.

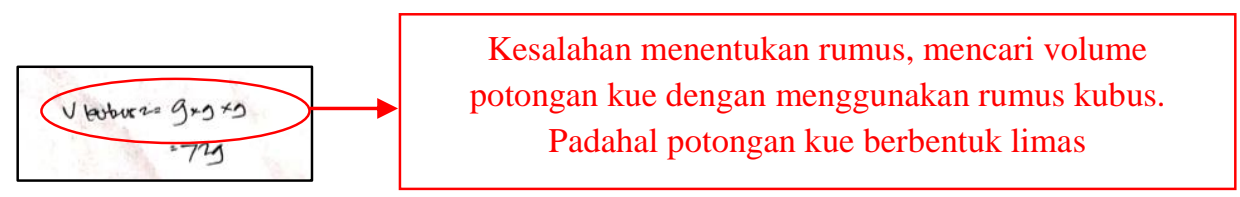

Gambar 5 Kesalahan menentukan rumus oleh S3

Sesuai pada hasil wawancara, hal ini terjadi dikarenakan S3 tidak memahami konsep soal. Selain itu, S3 juga tidak cermat dan teliti dalam memahami soal.

Indikator ketidaksesuaian dalam penggunaan rumus, teorema atau definisi dengan kondisi prasyarat berlakunya rumus, teorema atau definisi terbagi menjadi dua yaitu ketidaksesuaian rumus dan ketidaksesuaian teorema atau definisi. Indikator ketidaksesuaian rumus hanya 
dipunyai oleh S2. S2 melakukan kesalahan yaitu pada jawaban soal nomor 1, S2 menuliskan simbol L tetapi rumus yang diberikan adalah rumus volume.

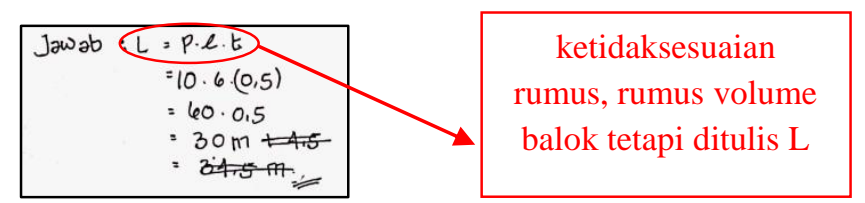

Gambar 6 Ketidaksesuaian rumus S2

Hal ini terjadi karena S2 kurang teliti dalam mengerakan. Sedangkan indikator ketidaksesuaian teorema atau definisi dilakukan oleh semua subjek. Pada soal nomor 1, S1 dan S3 merasa kebingungan dengan definisi luas alas prisma. Padahal di dalam soal nomor 1 luas alas belum diketahui dan harus dicari terlebih dahulu. Begitu juga kesalahan pada definisi tinggi prisma, hal ini dikarenakan S1, S2 dan S3 tidak memahami konsep soal. Tinggi prisma dalam soal nomor 1 diketahui dengan mengurangi tinggi tenda keseluruhan dengan tinggi balok atau badan tenda. Seharusnya tinggi tenda hanya 4 meter karena 4,5 - 0,5. Bukan lagi 4,5 meter seperti yang dituliskan oleh S1, S2 dan S3.

a

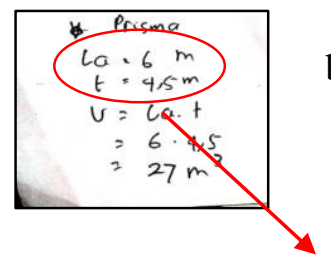

$\mathrm{b}$

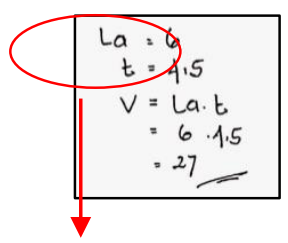

c

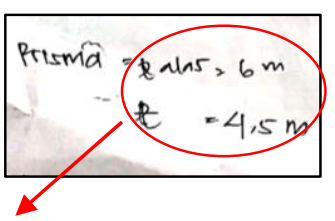

Ketidaksesuaian penggunaan teorema atau definisi, seharusnya $l$ bukan $\mathrm{L}_{\mathrm{a}}$ dan $\mathrm{t}=4$

Gambar 7 Ketidaksesuaian teorema atau definisi soal 1 oleh S1(a), S2(b), S3(c)

Sedangkan pada soal nomor 2 ketidaksesuaian teorema atau definisi dilakukan oleh S1 dalam memahami konsep alas dan luas alas dalam mencari volume limas. Pada lembar jawaban $\mathrm{S} 1$ menunjukkan $\mathrm{La}=9$, padahal nilai 9 itu adalah nilai dari alas limas. Kesalahan ini juga terjadi karena S1 tidak memahami konsep soal nomor 2.

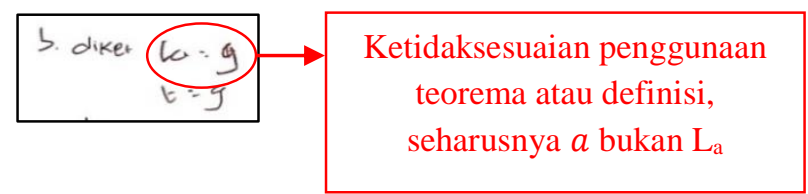

Gambar 8 Ketidaksesuaian teorema atau definisi soal 2 oleh S1

Indikator hambatan konseptual yang terakhir yaitu rumus, teorema dan definisi tidak ditulis untuk menjawab suatu masalah. Indikator ini dilakukan oleh semua subjek dalam menjawab soal nomor 2. S1 dan S2 melakukan kesalahan indikator tersebut dalam mencari volume limas, sedangkan S3 melakukan kesalahan tersebut dalam mencari volume kedua bangun. S1, S2 dan S3 langsung menuliskan nilai dari masing-masing simbol dan melakukan 
perhitungan tanpa menuliskan rumus yang digunakan. Pada saat wawancara, S1 mengaku hal itu dilakukannya untuk meringkas waktu agar lebih cepat dalam menjawab. indikator ini sering dilakukan S1 dalam menjawab soal-soal lainnya. Sedangkan S2 tidak menuliskan rumusnya dikarenakan lupa. Tetapi S2 juga mengaku bahwa ia sering tidak menuliskan rumus dalam menjawab soal sama seperti yang dilakukan S2. Sedangkan S3 tidak menuliskan rumus dikarenakan rasa malas yang dialami S3. Selain malas, S3 juga mengungkapkan hal itu ia lakukan untuk meringkas waktu agar tidak terlalu lama. Sama seperti S1 dan S2, S3 juga sering melakukan hal ini dalam menjawab soal.

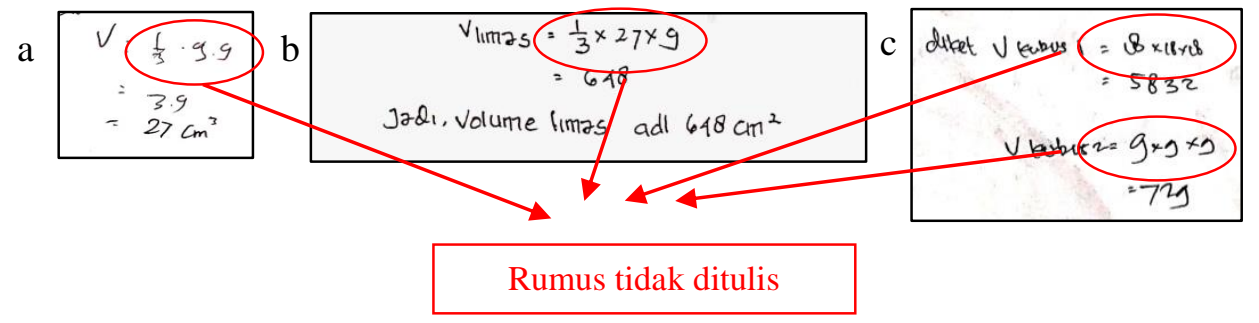

Gambar 9 Rumus tidak ditulis oleh S1(a), S2(b), S3(c)

Berdasarkan indikator hambatan konseptual, banyak siswa yang mengalami hambatan ini. Hal ini dikarenakan banyak siswa yang masih belum bisa mengembangkan pola pikir untuk mengaplikasikan konsep soal. Hambatan konseptual ini juga merupakan hambatan yang paling banyak ditemui pada ketiga subjek, baik pada soal nomor 1 maupun soal nomor 2 . Hasil penelitian ini sejalan dengan hasil penelitian Setiawati (2011) bahwa siswa madrasah aliyah mengalami kesulitan pada bentuk variabel atau yang tidak diketahui. Siswa cenderung bergantung pada bentuk yang sudah diketahui. Hal ini juga dikarenakan siswa tidak mampu mengembangkan konsep soal yang diberikan. Banyak juga siswa yang tidak menuliskan rumusnya karena tidak membiasakan diri untuk selalu menuliskannya pada jawaban. Sehingga dapat disimpulkan bahwa siswa mengalami hambatan epistemologi. Hambatan ini tidak akan terjadi jika siswa tidak berpatok pada soal yang sudah ada dan mampu mengembangkan pola pikir dalam mengerjakan suatu masalah baru. Siswa juga harus bisa membiasakan diri menulis rumus-rumus yang diperlukan dalam mengerjakan soal.

\section{Hambatan Prosedural}

Hambatan prosedural terjadi pada indikator siswa tidak menyelesaikan soal sampai pada bentuk paling sederhana sehingga perlu dilakukan langkah-langkah lanjutan. Indikator ini ditemui pada S2 pada soal nomor 1 dan 2. Pada saat wawancara, S2 mengatakan bahwa langkah-langkah yang dilakukan untuk menjawab soal nomor 1 yaitu hanya dengan mencari volume balok dan volume prisma. Sedangkan pada soal nomor 2 hanya dengan mencari volume kubus dan volume limas saja. Hal ini tidak sesuai dengan prosedur yang diharapkan peneliti. Karena seharusnya ada langkah terakhir untuk menentukan simpulan dari soal nomor 
1 dan 2.. Hambatan prosedural ini terjadi juga dikarenakan kurangnya kemampuan S2 dalam memahami konsep soal.

Selain indikator di atas, kesalahan prosedural juga terdapat pada tidak ditulisnya simbol-simbol yang diketahui pada soal. Kesalahan ini dilakukan oleh S2 dan S3 pada soal nomor 2, dimana S2 dan S3 tidak menuliskan hal-hal yang diketahui dalam soal untuk mencari volume, baik volume kubus maupun volume limas. Kesalahan ini terjadi pada S2 dan S3 dengan alasan yang sama, yaitu karena rasa malas, S2 juga beranggapan untuk mempercepat waktu. Sehingga hal tersebut tidak dituliskan, karena menurutnya tidak penting.

Hambatan prosedural dari masing-masing indikator di atas timbul dari faktor internal subjek. Jika subjek mampu mencermati soal, subjek dapat menemukan solusi langkah-langkah tersebut seperti yang dilakukan oleh S1 dan S3 pada soal nomor 1. Selain itu, subjek juga harus mencoba untuk membiasakan diri untuk menuliskan simbol-simbol yang diketahui di dalam soal. Sehingga tidak akan ada hambatan prosedural yang terjadi.

\section{Hambatan Teknik Operasional}

Seperti hambatan konseptual, hambatan teknik operasional semua indikator hambatan juga dapat ditemukan pada semua subjek. Pada indikator kesalahan hitungan nilai dari suatu operasi hitung dilakukan oleh S2 pada soal nomor 2. S2 melakukan kesalahan dalam menghitung $18 \times 18 \times 18=4212$. Padahal hasil sebenarnya adalah 5832 . Hal ini terjadi karena S2 tidak teliti dalam menghitung

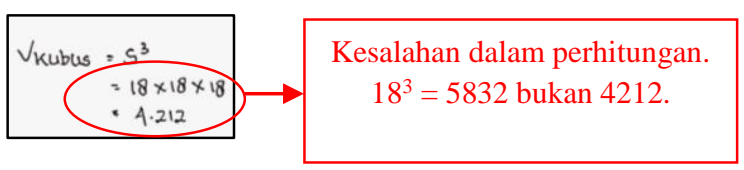

Gambar 10 Kesalahan dalam perhitungan oleh S2

Indikator kesalahan dalam penulisan, terbagi menjadi empat yaitu kesalahan penulisan satuan, kesalahan penulisan simbol, kesalahan penulisan rumus, dan kesalahan penulisan operasi hitung. Dalam kesalahan penulisan satuan dipunyai oleh S1 dan S3 dalam menjawab soal nomor 1. S1 salah menuliskan satuan tinggi. Dimana seharusnya satuan tinggi adalah meter, tetapi S1 menulis meter kubik pada satuan tinggi. Sedangkan kesalahan yang dilakukan S3 yaitu kesalahan penulisan satuan pada satuan luas yang seharusnya satuan luasnya adalah sentimeter persegi bukan hanya sentimeter.

a

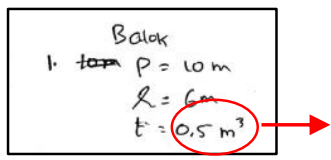

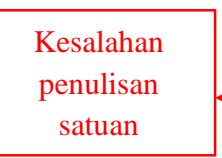

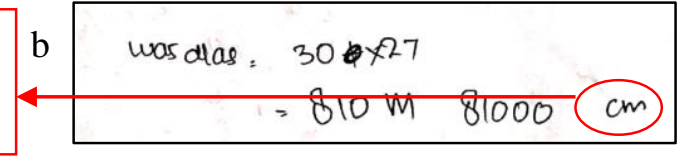

Gambar 11 Kesalahan penulisan pada soal 1 oleh S1(a) dan S3(b)

Pada soal nomor 2, indikator ini dilakukan oleh S2 dan S3 dalam menuliskan satuan volume. Pada instrumen jawaban S2 menuliskan satuan volumenya adalah sentimeter persegi, 
sedangkan S3 menuliskan satuan hanya sentimeter. Padahal seharusnya, satuan volume tersebut adalah sentimeter kubik. Jadi seharusnya S2 dan S3 menulis sentimeter kubik, bukan sentimeter persegi atau hanya sentimeter saja. Kesalahan-kesalahan dari hambatan ini terjadi karena subjek kurang teliti dalam mengerjakan soal.

a

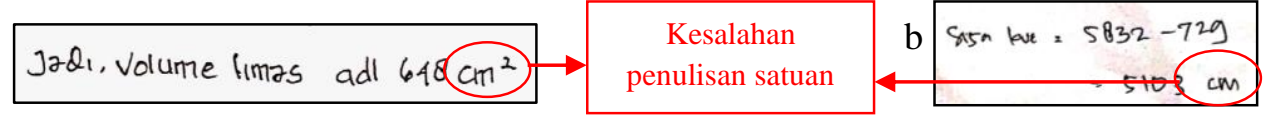

Gambar 12 Kesalahan penulisan pada soal 2 oleh S2(a) dan S3(b)

Kesalahan penulisan simbol dilakukan oleh S2. Berbeda dengan S1, dimana S1 menuliskan $\mathrm{La}=6$ dikarenakan salah konsep. Sesuai dengan hasil wawancara, S2 mengakui bahwa ia salah dalam menuliskan $\mathrm{La}=6$. S2 menyadari bahwa yang dimaksud nilai 6 itu bukan luas alas, tetapi lebar dari alas yang berbentuk balok. Lagi-lagi hal ini dikarenakan S2 tidak teliti dalam mengerjakan soal yang diberikan.

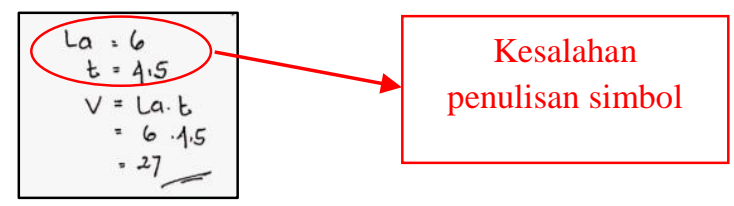

Gambar 13 Kesalahan penulisan simbol oleh S2

Kesalahan penulisan rumus dan operasi hitung dilakukan oleh S3 dalam mengerjakan soal nomor 1. Kesalahan penulisan rumus dilakukan dalam menuliskan rumus luas permukaan. Pada hasil wawancara, S3 mengaku bahwa ia salah dalam menuliskan rumus luas permukaan balok. S3 malah menuliskan rumus volume balok. Hal ini menyebabkan S3 mengalami kesalahan dalam perhitungan. Sedangkan pada kesalahan dalam penulisan operasi hitung terjadi pada saat S3 melakukan perhitungan untuk mencari luas keseluruhan. Dalam hasil wawancara S3 juga menyadari kesalahan yang ia buat. Hal ini menunjukkan bahwa hambatan yang dipunyai S3 ini dikarenakan S3 kurang cermat dan teliti dalam mengerjakan soal nomor 1 .

a

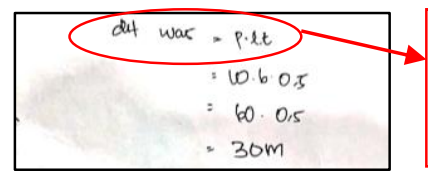

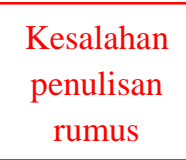

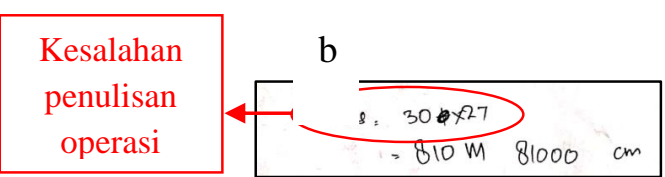

(a) dan operasi (b) oleh S3

Pada hambatan teknik operasional, hampir semua subjek mengalami hambatan. Hal ini dikarenakan subjek yang tidak cermat dan tidak teliti dalam membaca dan mengerjakan soal. Kasus yang sama juga terdapat pada penelitian yang dilakukan Rasmania, Sugiatno, dan Dede Suratman (2018). Dalam penelitiannya, terdapat siswa yang mempunyai hambatan dikarenakan siswa belum dapat membaca soal dengan baik. Siswa juga tidak melakukan 
pemeriksaan kembali pada jawaban tes yang dikerjakannya. Jika subjek dapat menyelesaikan masalah dengan cermat dan teliti, maka hambatan teknik operasional tidak akan terjadi.

\section{Kesimpulan}

Hambatan konseptual ditemukan pada indikator kesalahan penentuan rumus, ketidaksesuaian penggunaan teorema atau definisi, dan rumus, teorema, atau definisi tidak ditulis untuk menjawab soal. Hal ini dikarenakan subjek yang belum dapat menganalisa konsep soal yang diberikan serta malas untuk menuliskan rumus, teorema atau definisi tersebut. Hambatan prosedural ditemukan pada saat penyusunan langkah-langkah dan simbolsimbol dalam menjawab suatu permasalahan. Hal ini dikarenakan siswa belum mampu mengenali kondisi yang diberikan oleh suatu konsep. Hambatan teknik operasional sering ditemukan pada kesalahan siswa dalam menulis sehingga menimbulkan kesalahan siswa dalam perhitungan. Hambatan ini terjadi dikarenakan siswa masih kurang cermat dan teliti dalam menjawab suatu permasalahan. Pemaparan simpulan diatas juga terjadi karena siswa masih banyak yang berpatok pada beberapa contoh soal yang sudah diberikan oleh guru dengan jenis soal yang berbeda. Siswa belum mampu mengembangkan dan mengkreasikan pola berpikir untuk menjawab soal, sehingga siswa mengalami hambatan epistemologi.

Beberapa saran dari hasil penelitian ini, yaitu siswa harus lebih sering melatih kemampuan memahami konsep dan harus mampu menghilangkan rasa malasnya untuk menghindari hambatan konseptual. Untuk menghindari hambatan prosedural, siswa harus membiasakan diri untuk menuliskan hal-hal yang diperlukan, seperti apa saja yang diketahui dalam soal dan juga menuliskan rumus yang akan digunakan. Untuk menghindari hambatan teknik operasional, siswa diharapkan agar dapat lebih cermat dan teliti dalam mengerjakan masalah agar tidak ada kesalahan penulisan dan perhitungan dan usahakan untuk membiasakan diri memeriksa kembali jawaban yang sudah dikerjakan.

\section{Pustaka}

Brousseau. (2002). Theory of Didactical Situation in Mathematics. Dordrecth : Kluwer Academia Publisher.

Dedy, E., \& Sumiaty, E. (2017). Desain didaktis bahan ajar matematika smp berbasis learning obstacle dan learning trajectory. Jurnal Review Pembelajaran Matematika, 2(1), 69-80.

Hanafi. (2015). Desain didaktis pembelajaran matematika untuk mengatasi hambatan epistemologis pada konsep limit fungsi aljabar. Skripsi. Universitas Islam Negeri Sunan Ampel, Surabaya.

Hayati, I. N. (2009). Implementasi pembelajaran dengan pendekatan reciprocal teaching sebagai upaya meningkatkan kemandirian belajar matematika dan hasil belajar matematika untuk pokok bahasan kesebangunan pada siswa kelas IX-I SMP Negeri 1 Pacitan. Skripsi. Universitas Negeri Yogyakarta, Yogyakarta. 
Kastolan, dkk. (1992). Identifikasi jenis-jenis kesalahan menyelesaikan soal-soal matematika yang dilakukan siswa kelas II program A1 SMA negeri se-kotamadya Malang. Malang: IKIP Malang.

Maharani, H. R., Sukestiyarno, Y. L., Waluya, St. B., \& Mulyono. (2018). Alternative technique for assessing mathematical creative thinking in geometry based on information processing taxonomy model. International Conference on Science and Education and Technology 2018, 247, 228-232.

Rasmania, Sugiatno, \& Suratman, D. (2018). Hambatan epistemologis siswa dalam menentukan domain dan range fungsi kuadrat di sekolah menengah atas. Jurnal Pendidikan dan Pembelajaran, 7(7), 1-9.

Sears, R. (2018). The implications of pacing guide on the development of students ability to prove in geometry. International Electronic Journal of Mathematics Education, 13(3), 171-183.

Setiawati, E. (2011). Hambatan epistemologi (epistemological obstacles) dalam persamaan kuadrat pada siswa madrasah aliyah. Building the Nation Character through Humanistic Mathematics Education: Proceeding International Seminar and the Fourth National Conference on Mathematics Education. Diselenggarakan oleh Program Studi Pendidikan Matematika, UNY.

Xiao, K., \& Kenan, F. (2018). Seeing and the ability to see: a framework for viewing geometric cube problems. International Electronic Journal of Mathematics Education, 13(2), 57-60. 
